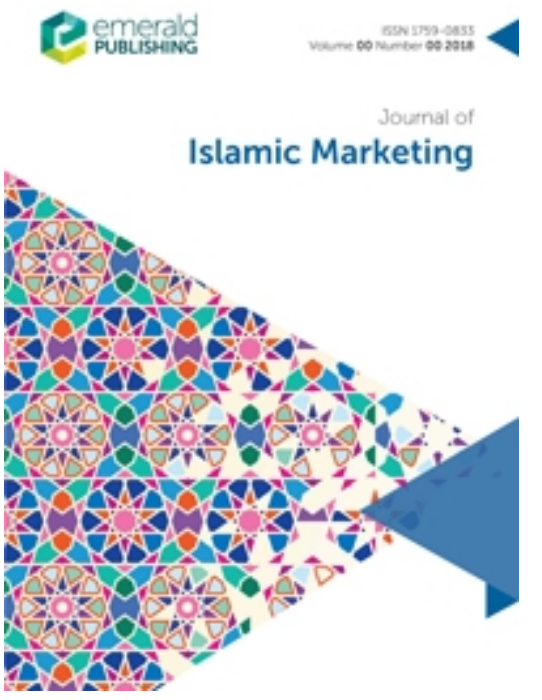

\title{
SERVICE QUALITY, RELIGIOSITY, CUSTOMER SATISFACTION, CUSTOMER ENGAGEMENT AND ISLAMIC BANKS' CUSTOMER LOYALTY
}

\begin{tabular}{|r|l|}
\hline Journal: & Journal of Islamic Marketing \\
\hline Manuscript ID & JIMA-03-2019-0044.R2 \\
\hline Manuscript Type: & Research Article \\
\hline Keywords: & $\begin{array}{l}\text { Customer Loyalty, Customer Satisfaction, Customer Engagement, } \\
\text { Service Quality, Religiosity, Islamic Bank }\end{array}$ \\
\hline \multicolumn{2}{|l}{} \\
\hline
\end{tabular}

\section{SCHOLARONE ${ }^{m}$ Manuscripts}




\title{
SERVICE QUALITY, RELIGIOSITY, CUSTOMER SATISFACTION, CUSTOMER ENGAGEMENT AND ISLAMIC BANK'S CUSTOMER LOYALTY
}

\begin{abstract}
Purpose

This study investigates the influential factors of customer loyalty to Islamic Bank, namely service quality, customer satisfaction, customer engagement and religiosity.

Design/methodology/approach

This study is a survey of 335 Islamic bank customers in West Sumatra Indonesia. This research deployed purposive sampling and analyzed the data by using Covariance Based Structural Equation Modelling (CBSEM).

\section{Findings}

Service quality has a positive and significant impact on customer satisfaction. Religiosity has a significant and negative moderating impact on the service quality-customer satisfaction relationship. Service quality has no significant influence on customer loyalty. Customer satisfaction is a significant antecedent of customer engagement and loyalty. Finally, customer engagement has a significant and positive effect on customer loyalty.

\section{Research limitations/implications}

This study is a combination of cross-sectional and a single country case. Accordingly, the results may not be representative of other countries. Similar studies in longitudinal data collection and conducted in other countries (e.g., ASEAN countries) would therefore be worthwhile. Some antecedents of customer loyalty have been neglected in this study (e.g., customer value co-creation and customer commitment), hence, the future study may investigate those factors.
\end{abstract}

\section{Practical implications}

By considering these Islamic banks' antecedents, the Islamic banks might enhance their customer loyalty. Second, this study has revealed the moderating role of religiosity in a loyalty relationship. Therefore, it will give insights for the Islamic bank managers in decision making.

\section{Originality/value}

This study has revealed the moderating role of religiosity on the link between service quality and customer satisfaction in Islamic bank which is neglected in the previous studies. The customers with high religiosity will have a higher standard of satisfaction and demand a better service quality than the customers with low religiosity. This study has also examined the relationship between service quality, religiosity, customer satisfaction, customer engagement and loyalty as a whole which have been limited previously.

KEYWORDS: Customer Loyalty; Customer Satisfaction, Customer Engagement; Service Quality; Religiosity; Islamic Bank

\section{INTRODUCTION}

Banking sector is an important sector in the global financial system. The banking sector has the biggest market share in the financial business (Darsono et al., 2017). Financial Services Authority survey in 2016 revealed that the index of financial inclusion in Indonesia was 67,82\% (Otoritas Jasa Keuangan, 2017). Furthermore, Indonesia is already known as the country with the largest Muslim population in the world. From the Islamic perspective, all activities, including business and economics have to comply with Islamic law (Darsono et al., 2017). 
The Indonesian government introduced the Islamic bank in 1991 by establishing Bank Muamalat. In 2008, the government introduced the enactment of Act no. 21 of 2008 (UU No. 21 2008) about Islamic bank. Thus, this policy has increased the number of Islamic banks (Otoritas Jasa Keuangan, 2017). However, the market share of Islamic bank in Indonesia is still low. For example, the market share of Islamic bank in March 2019 was only $5.94 \%$ (Otoritas Jasa Keuangan, 2019). Moreover, West Sumatra, the home territory of Minangkabau, is well-known as the religious province where its motto is “Adat Basandi Syara', Syara' Basandi Kitabullah". This motto means that all activities in the Minangkabau culture should be based on Islamic law. Presumably, Islamic banking is more prevalent in West Sumatra than in other provinces. In contrast, the Financial Services Authority found that the market share of Islamic bank in West Sumatera is still small (Otoritas Jasa Keuangan, 2019). Accordingly, this is the main reason why we conducted this research in West Sumatra.

One important factor in managing a service business such as a bank is enhancing customer loyalty (Bruneau et al., 2018). When a customer is loyal to the product or brand, he/she is more likely to purchase or recommend the product to other people. Accordingly, we assume that customer loyalty is a potential factor of the small market share of Islamic banking in Indonesia. According to Murali et al. (2016), loyalty is the result of an organization creating a benefit for the customers so that they will maintain or increase their purchases (p.69). Previous studies have revealed some antecedents of customer loyalty, such as customer satisfaction, customer engagement and service quality (Han and Hyun, 2018, Kamran-Disfani et al., 2017, Meesala and Paul, 2018, Bruneau et al., 2018, Vera and Trujillo, 2013). This study aims to examine the link between service quality, customer engagement, customer satisfaction and customer loyalty. Surprisingly, this study also investigates the moderating role of religiosity on the link between service quality and customer satisfaction which is limited previously. Eid and El-Gohary (2015) and Zamani-Farahani and Musa (2012) have investigated the role of religiosity on customer satisfaction. They argue that people with high religiosity will perceive their satisfaction differently when they perceived the service quality of a company. However, they studied in the tourism sector and the study on this relationship is still neglected in other service businesses such as Islamic bank. Therefore, we argue that studies on these topics in other service sectors are still valuable.

This study has some contributions, including theoretical contribution and managerial implication. The first theoretical contribution of this study is that this study has investigated the 
negative moderating effect of religiosity on service quality-customer satisfaction relationship. Customers high religiosity will demand more on service quality which will decrease their satisfaction compared to customers with low religiosity. The customers with high religiosity have more knowledge of how Islamic banks should give their services based on Islamic compliance. Accordingly, they will have a higher expectation than customers with low religiosity. Secondly, this study has also revealed the link between service quality, customer satisfaction, customer engagement, religiosity and customer loyalty as a whole. The previous researchers have addressed those relationships partially (Meesala and Paul, 2018, Eid and El-Gohary, 2015, Prentice et al., 2019), however, they failed to examine all those variables in one study. Therefore, this study has contributed to examine all variables as a whole which were limited in the prior studies.

Moreover, this study has also contributed to managerial decision making. Islamic banks' managers in Indonesia have to concern with the antecedents of customer loyalty if they want to increase the participation rate of the customers. The most influencing factor in customer loyalty is customer engagement. Besides, customer engagement is affected by customer satisfaction and service quality. Hence, the managers must deal with service quality as the main influential factor of customer satisfaction and customer engagement which will have a positive indirect effect on customer loyalty.

\section{LITERATURE REVIEW}

\section{Customer Loyalty}

Customer loyalty is an important factor in managing service such as banking sector (Kamran-Disfani et al., 2017). According to Thakur (2016), "loyalty is a customer's intention or predisposition to purchase from the same seller or the same brand again and is an outcome of the conviction that the value received from the said seller/ brand is higher than the value available from other alternatives" (p.153). Han and Hyun (2018) argue that loyal customers bring enormous advantages to every firm, such as allowing for a continuous profit stream and reduction of marketing/promotion costs (p.75). Loyalty has some antecedents, such as customer satisfaction, customer engagement, service quality and customer perceived value (Akamavi et al., 2015, Han and Hyun, 2018, Bruneau et al., 2018, Raïes et al., 2015). According to Meesala and Paul (2018), customer loyalty can be measured by using some items, such as the intention to buy more products, 
prefers to buy that product compared to the competitor and the willingness to recommend the product to other potential customers.

\section{Religiosity}

Religiosity refers to people expression on their religious beliefs and practices (Johan and Putit, 2016). Religiosity is already known as one of the most influential factors of human behavior (Eid and El-Gohary, 2015). According to Zamani-Farahani and Musa (2012), religiosity has two dimensions, including religious beliefs and religious practices. Religious beliefs refer to what people believe about all activities based on their religious point of view; meanwhile, religious practice is related to how they do every activity based on their religious values. In the Islamic context, the example of religious beliefs is "their belief that Allah (God) will help them". The example of religious practices is "their consistency in doing prayers every day".

\section{Service Quality, Religiosity and Customer Satisfaction}

In managing a service business, customer satisfaction becomes an important factor for the company (Cheshin et al., 2018). According to Murali et al. (2016), customer satisfaction refers to the degree of customer perceived performance compared to customer expectation. A customer will be satisfied when his/her perceived performance is the same with or more than his/her expectation (Meesala and Paul, 2018). Moreover, Han and Hyun (2018) assert that customer satisfaction deals with the level of pleasurable of the customer in the consumption fulfilment. Accordingly, we argue that satisfaction of the Islamic bank's customer is the level of pleasurable consumption fulfilment of the customers compared to their expectation and perceived service quality.

Customer satisfaction has some antecedents, such as service quality and religiosity (Miranda et al., 2017, Eid and El-Gohary, 2015). Some previous studies have found that service quality has a significant impact on customer satisfaction (Meesala and Paul, Miranda et al., 2017, Murali et al., 2016, Vera and Trujillo, 2013). Miranda et al. (2017) assert that service quality is the customer's perceived value of the service by comparing between perceived quality and service expectation. Meesala and Paul (2018) have investigated the link between service quality, customer satisfaction and customer loyalty in 40 private Indian Hospitals. They found that service quality has a significant impact on customer satisfaction. Furthermore, Vera and Trujillo (2013) have 
found that customer satisfaction is a consequence of service quality. Accordingly, we argue that service quality has a relationship with customer satisfaction (Miranda et al., 2017). From the discussion above we hypothesize that service quality has a positive and significant impact on Islamic banks' customer satisfaction (H1).

Some previous studies have argued that religiosity may relate to customer service quality and customer behavior (Cantrell and Yust, 2018, Aysan et al., 2018, Gursoy et al., 2017). According to Eid and El-Gohary (2015), the link between customer value and customer satisfaction has been moderated by religiosity. They found that religiosity is a significant moderating factor in the relationship between customer value and customer satisfaction. Moreover, Zamani-Farahani and Musa (2012) have asserted that religiosity has an impact on the sociocultural perceived value of tourists. Customer's perceived value is closely related to perceived service quality. Accordingly, religiosity may also affect the link between service quality and customer satisfaction. Therefore, we posit that religiosity has a moderating impact on the relationship between customer service quality and customer satisfaction $(\mathrm{H} 2)$.

\section{Service Quality and Customer Engagement}

Some prior studies have attempted to explain that service quality is related to customer engagement (Lee et al., 2018, Roy et al., 2018a, Roy et al., 2018b, Verleye et al., 2013). Customer engagement refers to emotional bonding with a brand or medium which leads to more interaction with the object (Thakur, 2018). Roy et al. (2018b) have highlighted the significant effect of service convenience on customer engagement. Verleye et al. (2013) assert that overall service quality will have a significant influence on customer engagement behavior. In one hand, Ahn and Back (2018) assert that customer brand experience is a positive and significant antecedent of customer engagement. On the other hand, the brand experience is closely related to perceived service quality. Accordingly, we argue that when a customer has got a better service quality, it means that he/she has got a better brand experience and will have an intention to be engaged with the product or brand. Therefore, we propose a hypothesis that service quality is a significant antecedent of customer engagement $(\mathrm{H} 3)$.

\section{Service Quality and Customer Loyalty}


Service quality might have a significant effect on customer loyalty (Meesala and Paul, 2018, Murali et al., 2016, Vera and Trujillo, 2013). Murali et al. (2016) have examined the link between customer satisfaction and customer loyalty in India. They studied 510 customers of a home appliances business. Their study found that service quality is a significant antecedent of customer loyalty. Meanwhile, Meesala and Paul (2018) have also studied the relationship between service quality and customer loyalty in 40 hospitals. They surveyed 180 undergone patients and found that service quality has a direct and positive impact on customer loyalty. In addition, Vera and Trujillo (2013) have also revealed that service quality has a direct and indirect positive relationship with customer loyalty. Therefore, we argue that service quality is a positive antecedent of customer loyalty, then, we propose a hypothesis that service quality is a positive and significant influential factor of customer loyalty (H4).

\section{Customer Satisfaction and Customer Engagement}

Prior studies have asserted that customer satisfaction has a relationship with customer engagement (Thakur, 2018, Gopalakrishna et al., 2017, Carlson et al., 2017, Simon and Tossan, 2018). Carlson et al. (2017) have highlighted that customer satisfaction is a moderating variable of the link between the value in brand experience and customer engagement. Moreover, Simon and Tossan (2018) argue that customer satisfaction is also an antecedent of brand Facebook page engagement. Accordingly, when a customer is satisfied with the product or brand, it will have an impact on his/her engagement with the brand/product. In addition, Thakur (2018) has examined the positive and significant relationship between customer satisfaction with retailer and customer engagement with the retailer mobile apps. He asserts that customer engagement will increase when the customer has satisfied with the retailer product and service. Therefore, we posit that customer satisfaction is a significant antecedent of customer engagement (H5).

\section{Customer Satisfaction and Customer Loyalty}

Many previous studies have found that customer satisfaction has a significant effect on customer loyalty (Han and Hyun, 2018, Kamran-Disfani et al., 2017, Meesala and Paul, 2018, Murali et al., 2016, Vera and Trujillo, 2013). Meesala and Paul (2018) assert that one of the antecedents of customer loyalty is customer satisfaction. When a customer has satisfied with the service quality, he/she will be loyal to the product or service. Murali et al. (2016) have found a similar finding that customer satisfaction will lead to customer loyalty. Moreover, Kamran-Disfani 
et al. (2017) have examined the link between satisfaction and loyalty in home business appliance shoppers. They found that satisfaction has a significant impact on attitudinal and behavioral loyalty. Accordingly, we argue that this relationship will also occur in the Islamic banking sector. However, this relationship has been investigated in other service sectors and the study on this link is still neglected in the Islamic financial sector. Therefore, we posit that customer satisfaction will positively and significantly influence the loyalty of the Islamic bank's customer (H6).

\section{Customer Engagement and Customer Loyalty}

According to some previous studies, customer engagement may influence customer loyalty (Chen and Rahman, 2017, Prentice et al., 2019, Roy et al., 2018b, Lee et al., 2018). Prentice et al. (2019) have examined the relationship between social identification, customer engagement and purchase intention of a social community. They have asserted that customer engagement is a positive and significant antecedent of purchase intention. Furthermore, Lee et al. (2018) highlight that customer engagement is a mediating variable of the relationship between channel integration quality and repurchase intention. Meanwhile, repurchase intention is closely related to loyalty (Kingshott et al., 2018). Accordingly, we argue that customer engagement will have a significant influence on customer loyalty. We propose a hypothesis that customer engagement has a significant and positive impact on customer loyalty $(\mathrm{H} 7)$.

\section{RESEARCH METHOD}

\section{Population and Sample}

The population of this study is all customers of Islamic banks in West Sumatra. We collected the data from 4 municipals/cities in West Sumatra which have Islamic banks (Otoritas Jasa Keuangan, 2017). The number of samples of this study is 400 respondents. The questionnaire of this study has 38 items. According to Hair et al. (2010), the number of samples should be 5-20 times of the number of items. In addition, the number of samples should be more than 200 because this study used Structural Equation Modelling (SEM) as the data analysis technique (Byrne, 2010).

\section{Measurement Development}

This study has constructed the variable measurement from some previous studies. There are five variable constructs in this research, including customer loyalty, customer engagement, 
customer satisfaction, religiosity and service quality. We adopted the measurement of customer loyalty from Meesala and Paul (2018). The variable of customer engagement has been taken from Verhagen et al. (2015). Moreover, we adopt customer satisfaction measurements from Meesala and Paul (2018). Religiosity construct in this research has been adopted from Eid and El-Gohary (2015). Finally, we use bank service quality measurements from Karatepe et al. (2005).

\section{Data Collection Procedures}

This study has employed some steps in data collection procedures. Firstly, we have developed the questionnaires and translated them to Bahasa Indonesia by using a back-translation procedure (Sekaran and Bougie, 2013). We deploy a five-point Likert scale from Strongly disagree (1) to Strongly Agree (5). Secondly, we have done a pilot test to 30 respondents for ensuring the clarity of the items, wording, items relevancy, words and phrases bias and format of the questionnaire (Lee et al., 2018). Thirdly, after the pilot test, we distributed 400 questionnaires to 4 municipals/cities in West Sumatra which have Islamic bank branches (Otoritas Jasa Keuangan, 2017, Darsono et al., 2017). This study employed purposive sampling as the sampling method with two criteria (Sekaran and Bougie, 2013). The respondent criteria of this study are (1) Islamic bank's customers and (2) active customers in doing transaction within the last three months.

\section{Data Analysis}

This study employed Covariance Based Structural Equation Modelling (CB SEM) by using AMOS 24 as the software package (Byrne, 2010). In conducting SEM, we will meet the Goodness of Fit criteria (GoF). The criteria of GoF included Normed Chi-square (CMIN/DF), Comparative Fit Index (CFI), Tucker-Lewis Index (TLI), Adjusted Goodness of Fit Index (AGFI) and Goodness of Fit Index (GFI), and Root Mean Square Error of Approximation (RMSEA) (Byrne, 2010). The cut-off points for those criteria are $<5$ for CMIN/DF, $\geq 0.90$ for CFI, TLI and GFI, $\geq 0.80$ for AGFI and $\leq 0.08$ for RMSEA (Bentler and Bonett, 1980, Akamavi et al., 2015, Wardi et al., 2018a). However, before the main analysis, we have done some preliminary analysis, such as outliers, normality (Patrisia and Dastgir, 2017), multicollinearity and heteroscedasticity test (Pallant, 2013, Hair et al., 2010, Wardi et al., 2018b). Therefore, we found that the data were free from those preliminary data problems and we got 335 usable responses. Furthermore, we have also conducted the validity and reliability test. Table 1 shows the construct reliability and validity by 
using loading factor value $>0.5$ (Hair et al., 2010), Average Variance Extracted (AVE) value $>$ 0.5, Cronbach's Alpha > 0.7, and composite reliability $(\mathrm{CR})>0.7$ (Hair et al., 2014).

Insert Table 1 here

Moreover, this study has also examined discriminant validity by using Fornell-Larcker's criterion (Hair et al., 2014, Abror et al., 2019). In this test, we used the value of the square root of AVE as the cut-off point. Table 2 shows that the data have a good discriminant validity where the square root of AVE is greater than the cross-loading value. In addition, as this study is a crosssectional study, it used self-rated questionnaires. Accordingly, the common method bias is a possible problem that can occur (Podsakoff et al., 2003). Therefore, to anticipate this problem, we have done a common method bias test by using Harman's single factor method, hence, we found that the data were free from common method bias because the total variance for a single factor was 23.36\% (<40\%) (MacKenzie and Podsakoff, 2012, Wong et al., 2011).

Insert Table 2 here

\section{RESULTS AND ANALYSIS}

This study used descriptive statistic and SEM as the main data analysis. Accordingly, this analysis has three components, including description of respondents, measurement model and structural model (Byrne, 2010). Therefore, the results are described as follows.

\section{Description of Respondents}

Based on the descriptive statistic, this study found that most of the respondents have a monthly expenditure $\leq$ five million rupiah (94.5\%). The average the transaction in Islamic bank per month is less than 5 times $(87.9 \%)$. Most of the respondents are women $(57.1 \%)$ and their age is less than 40 years old (87.9\%). Finally, they are university graduates (95.7\%). Accordingly, we may assume that the customers of Islamic banks are people with a productive age and have a good education level.

\section{Measurement Model}

Figure 1 shows the measurement model of this study. Based on the criteria of the Goodness of Fit (GoF), we found that the measurement model has a good fit model. The value of CMIN/DF 
is $1.45(<5)$, the values of CFI, TLI and GFI are $0.98,0.97$ and 0.94 respectively $(\geq 0.90)$, the value of AGFI is $0.92(\geq 0.80)$ and the value of RMSEA is $0.04(<0.08)$.

Insert Figure 1 here

\title{
Structural Model
}

Figure 2 shows the structural model of this study. Before doing the path analysis of each relationship, we have examined the GoF of the structural model. We also found that the structural model has a good fit index. The value of CMIN/DF is $1.49(<5)$, the values of CFI, TLI and GFI are $0.99,0.98$ and 0.99 respectively $(\geq 0.90)$, the value of AGFI is $0.96(\geq 0.80)$ and the value of RMSEA is $0.04(<0.08)$. Furthermore, Table 3 shows the hypothesis testing of this model. We found that service quality has a significant direct impact on satisfaction $(\mathrm{H} 1 ; \beta=0.61 ; * * *)$ and customer engagement $(\mathrm{H} 3 ; \beta=0.28 ; * * *)$. Table 4 shows the link between service quality and customer satisfaction through religiosity as a moderating variable. This relationship is also significantly and negatively moderated by religiosity $(\mathrm{H} 2 ; \beta=-0.13 ; * *)$. However, service quality has no significant direct effect on customer loyalty $(\mathrm{H} 4 ; \beta=-0.05$; ns). Moreover, customer satisfaction has significant and direct impact on customer engagement (H5; $\beta=0.30 ; * * *)$ and customer loyalty $(\mathrm{H} 6 ; \beta=0.31 ; * * *)$. Finally, customer engagement also significantly affects customer loyalty $(\mathrm{H} 7 ; \beta=0.43 ; * * *)$.

\author{
Insert Figure 2 Here \\ Insert Table 3 Here \\ Insert Table 4 Here
}

\section{DISCUSSION}

This study found that service quality has a significant and positive impact on customer satisfaction (H1). This finding is in line with several prior studies (Miranda et al., 2017, Meesala and Paul, 2018, Vera and Trujillo, 2013). Customers will satisfy when they have perceived good service quality. In the Islamic bank context, the Islamic bank's manager or owner must concern with the quality of service such as the ability of the bank to help customers in doing a transaction; consequently, the bank has to provide reliable services (e.g., no long queue in transaction process) and create a warm relationship with the customers.

The moderating effect of religiosity on the relationship between service quality and customer satisfaction is also significant (H2), however, it has a negative relationship way. This 
finding is similar to some prior studies (Aysan et al., 2018, Cantrell and Yust, 2018, Eid and ElGohary, 2015). For instance, Eid and El-Gohary (2015) argue that religiosity has a significant moderating effect on the link between customer value and customer satisfaction in the tourism sector. Surprisingly, we found a negative moderating effect in this study which is neglected in the prior studies (Zamani-Farahani and Musa, 2012). Figure 3 shows the interaction effect between service quality and customer satisfaction with religiosity as the moderating variable. The negative moderating effect means that the religiosity will decrease the relationship between service quality and customer satisfaction. The plausible reason for this is that when a customer has a good Islamic religiosity, he/she will have good religious beliefs and practices, hence, he/she will comply with the Islamic roles and asks for a higher standard in service quality based on his/her religious beliefs. Accordingly, people with higher religiosity will perceive the service in a higher standard compared to people with lower religiosity. Therefore, the religiosity of the customers will dampen the link between service quality and customer satisfaction.

\section{Insert Figure 3 Here}

This study has examined the link between service quality and customer engagement. We found that service quality is a significant and positive antecedent of customer engagement (H3). This finding supports several prior studies which found that service quality may lead to customer engagement (Lee et al., 2018, Ahn and Back, 2018, Roy et al., 2018a). For example, Roy et al. (2018b) have investigated the impact of service convenience, fairness and quality on customer engagement. They found that service quality has a significant effect on customer engagement. When an Islamic bank has provided excellent service quality, it will create bonding with the customer. The customer will engage or the bonding may create more interaction between customer and company relating to customer engagement.

This study found that service quality has no significant direct effect on customer loyalty (H4). This finding does not support the prior studies who argue that service quality is an antecedent of customer loyalty (Meesala and Paul, 2018, Murali et al., 2016). However, the service quality has an indirect impact on customer loyalty through customer satisfaction as the mediating variable. The plausible reason on it is that customer satisfaction is the main influential factor of loyalty (Han and Hyun, 2018); meanwhile, Miranda et al. (2017) argue that service quality is one of the main factors in creating customer satisfaction. Accordingly, when a customer of Islamic bank has perceived good service quality, he/she will have a higher satisfaction level which may lead to 
his/her intention to be loyal with the Islamic bank. They might use the service more and will recommend that Islamic bank to others. Therefore, we argue that service quality is a significant factor in influencing customer loyalty through customer satisfaction as an intervening variable.

This research has highlighted that customer satisfaction affects customer engagement positively and significantly (H5). This finding is congruent with some prior studies (Carlson et al., 2017, Simon and Tossan, 2018). Simon and Tossan (2018) have mentioned that when the customers satisfied with the product, they will have a more possible chance to be engaged. Accordingly, Islamic banks must concern with customer satisfaction by providing better services which lead to their intention to engage and interact with the Islamic banks.

This study has also highlights that customer satisfaction positively and significantly influences customer loyalty (H6). This finding supports several prior studies (Han and Hyun, 2018, Meesala and Paul, 2018). For instance, Kamran-Disfani et al. (2017) have argued that customer satisfaction is an antecedent of customer loyalty (attitudinal and behavioral loyalty). Therefore, when the Islamic bank's customers have satisfied with the bank services, it will lead to their loyalty, such as increasing their transaction or recommend that bank to other people.

Finally, we found that customer engagement is also a positive and significant antecedent of customer loyalty (H7). This finding is in line with several studies (Prentice et al., 2019, Roy et al., 2018b, Lee et al., 2018). The customers of Islamic banks will have a higher loyalty level when they engage with the bank. Customer engagement which relates to their sense of belonging and the level of the customer involvement is a key point to create their bonding and it will lead to the degree of the customer loyalty (attitudinal or behavioral loyalty).

In conclusion, this study supports some prior studies on the relationship between services quality, religiosity, customer satisfaction, customer engagement and customer loyalty. This study has contributed to the theoretical and practical aspect. The first theoretical contribution of this study is the role of religiosity in moderating the link between service quality and customer satisfaction. The previous studies have neglected in examining such relationship (Zamani-Farahani and Musa, 2012, Eid and El-Gohary, 2015). Therefore, to the best of our knowledge, this is the first study which investigates the moderating role of religiosity on the link between service quality and Islamic bank customer satisfaction, especially in the Indonesian context. Moreover, the prior studies have only examined the link between service quality, customer satisfaction, customer engagement and customer loyalty partially (Thakur, 2016, Yao et al., 2019, Meesala and Paul, 


\section{REFERENCES}

Abror, A., Wardi, Y., Trinanda, O. \& Patrisia, D. (2019). "The impact of halal tourism, customer engagement on satisfaction: Moderating effect of religiosity". Asia Pacific Journal of Tourism Research, 24, 633-643.

Ahn, J. \& Back, K.-J. (2018). "Antecedents and consequences of customer brand engagement in integrated resorts". International Journal of Hospitality Management.

Akamavi, R. K., Mohamed, E., Pellmann, K. \& Xu, Y. (2015). "Key determinants of passenger

2018), whilst, this study has investigated all variables and employed religiosity as the mediating variable.

Furthermore, this study has also provided managerial implications. Firstly, this study may help the managers of Islamic banks in creating a loyalty program. They will concern with how to create better customer satisfaction and customer engagement by using better service quality. Thus, when the Islamic banks' managers provide a better service quality training for their employees and also maintain their physical facilities, it will have a positive impact on customer satisfaction and customer engagement as the antecedents of customer loyalty. Secondly, Islamic bank has a unique customer because it is related to religiosity. Therefore, the managers have to develop the Islamic bank's product by considering the religious rules because the religiosity of the customer will moderate the link between service quality and customer satisfaction.

\section{LIMITATION AND FUTURE RESEARCH}

This study has highlighted some contributions; however, it also has some limitations. First, it is a cross-sectional study. Therefore, for further study, we suggest to expand it to a longitudinal study which helps us to validate the causal mechanism and to get more generalized results. Second, this study is only a single country study (Indonesia). We suggest to expand it into other countires, such as ASEAN countries or other Muslim majority countries. Finally, this study only used service quality, customer satisfaction and customer engagement as the antecedents of customer loyalty. Therefore, for future studies we suggest to add other antecedents of customer loyalty, such as customer value co-creation, customer commitment. Furthermore, customer loyalty dimensions might be divided into attitudinal loyalty and behavioral loyalty (Meesala and Paul, 2018, Yao et al., 2019).

\footnotetext{
loyalty in the low-cost airline business". Tourism Management, 46, 528-545.

Akamavi, R. K., Moham.
} 
Aysan, A. F., Disli, M., Duygun, M. \& Ozturk, H. (2018). "Religiosity versus rationality: Depositor behavior in Islamic and conventional banks". Journal of Comparative Economics, 46, 1-19.

Bentler, P. M. \& Bonett, D. G. (1980). "Significance tests and goodness of fit in the analysis of covariance structures". Psychological Bulletin, 88, 588-606.

Bruneau, V., Swaen, V. \& Zidda, P. (2018). "Are loyalty program members really engaged? Measuring customer engagement with loyalty programs". Journal of Business Research, 91, 144-158.

Byrne, B. M. (2010). Structural equation modeling with amos: Basic concepts, applications, and programming, second edition, GB, Routledge Ltd.

Cantrell, B. W. \& Yust, C. G. (2018). "The relation between religiosity and private bank outcomes". Journal of Banking \& Finance, 91, 86-105.

Carlson, J., Rahman, M. M., Taylor, A. \& Voola, R. (2017). "Feel the vibe: Examining value-inthe-brand-page-experience and its impact on satisfaction and customer engagement behaviours in mobile social media". Journal of Retailing and Consumer Services.

Chen, H. \& Rahman, I. (2017). "Cultural tourism: An analysis of engagement, cultural contact, memorable tourism experience and destination loyalty". Tourism Management Perspectives.

Cheshin, A., Amit, A. \& van Kleef, G. A. (2018). "The interpersonal effects of emotion intensity in customer service: Perceived appropriateness and authenticity of attendants' emotional displays shape customer trust and satisfaction". Organizational Behavior and Human Decision Processes, 144, 97-111.

Darsono, Sakti, A., Suryanti, E. T., Astiyah, S. \& Darwis, A. (2017). Masa depan keuangan syariah indonesia, Jakarta, Indonesia, Tazkia Publishing kerjasama Bank Indonesia.

Eid, R. \& El-Gohary, H. (2015). "The role of islamic religiosity on the relationship between perceived value and tourist satisfaction". Tourism Management, 46, 477-488.

Gopalakrishna, S., Malthouse, E. C. \& Lawrence, J. M. (2017). "Managing customer engagement at trade shows". Industrial Marketing Management.

Gursoy, D., Altinay, L. \& Kenebayeva, A. (2017). "Religiosity and entrepreneurship behaviours". International Journal of Hospitality Management, 67, 87-94.

Hair, J. F., Black, W. C., Babin, B. J. \& Anderson, R. E. (2010). Multivariate data analysis, New Jersey, Prentice Hall.

Hair , J. F. J., Sarstedt, M., Hopkins, L. \& G. Kuppelwieser, V. (2014). "Partial least squares structural equation modeling (pls-sem)". European Business Review, 26, 106-121.

Han, H. \& Hyun, S. S. (2018). "Role of motivations for luxury cruise traveling, satisfaction, and involvement in building traveler loyalty". International Journal of Hospitality Management, 70, 75-84.

Johan, Z. J. \& Putit, L. (2016). "Conceptualizing the influences of knowledge and religiosity on islamic credit card compliance". Procedia Economics and Finance, 37, 480-487.

Kamran-Disfani, O., Mantrala, M. K., Izquierdo-Yusta, A. \& Martínez-Ruiz, M. P. (2017). "The impact of retail store format on the satisfaction-loyalty link: An empirical investigation". Journal of Business Research, 77, 14-22.

Karatepe, O. M., Yavas, U. \& Babakus, E. (2005). "Measuring service quality of banks: Scale development and validation". Journal of Retailing and Consumer Services, 12, 373-383. 
Kingshott, R. P. J., Sharma, P. \& Chung, H. F. L. (2018). "The impact of relational versus technological resources on e-loyalty: A comparative study between local, national and foreign branded banks". Industrial Marketing Management, 72, 48-58.

Lee, Z. W. Y., Chan, T. K. H., Chong, A. Y.-L. \& Thadani, D. R. (2018). "Customer engagement through omnichannel retailing: The effects of channel integration quality". Industrial Marketing Management.

MacKenzie, S. B. \& Podsakoff, P. M. (2012). "Common method bias in marketing: Causes, mechanisms, and procedural remedies". Journal of Retailing, 88, 542-555.

Meesala, A. \& Paul, J. (2018). "Service quality, consumer satisfaction and loyalty in hospitals: Thinking for the future". Journal of Retailing and Consumer Services, 40, 261-269.

Miranda, S., Tavares, P. \& Queiró, R. (2017). "Perceived service quality and customer satisfaction: A fuzzy set qca approach in the railway sector". Journal of Business Research.

Murali, S., Pugazhendhi, S. \& Muralidharan, C. (2016). "Modelling and investigating the relationship of after sales service quality with customer satisfaction, retention and loyalty - a case study of home appliances business". Journal of Retailing and Consumer Services, 30, 67-83.

Otoritas Jasa Keuangan 2017. Survey nasional literasi dan inklusi jasa keuangan 2016. Jakarta: Otoritas Jasa Keuangan.

Otoritas Jasa Keuangan 2019. Sharia banking statistics march 2019. Jakarta: Otoritas Jasa Keuangan.

Pallant, J. (2013). Spss survival manual: A step by step guide to data analysis using ibm spss, Maidenhead, McGraw-Hill.

Patrisia, D. \& Dastgir, S. (2017). "Diversification and corporate social performance in manufacturing companies". Eurasian Business Review, 7, 121-139.

Podsakoff, P. M., MacKenzie, S. B., Lee, J.-Y. \& Podsakoff, N. P. (2003). "Common method biases in behavioral research: A critical review of the literature and recommended remedies". Journal of Applied Psychology, 88, 879-903.

Prentice, C., Han, X. Y., Hua, L.-L. \& Hu, L. (2019). "The influence of identity-driven customer engagement on purchase intention". Journal of Retailing and Consumer Services, 47, 339 347.

Raïes, K., Mühlbacher, H. \& Gavard-Perret, M.-L. (2015). "Consumption community commitment: Newbies' and longstanding members' brand engagement and loyalty". Journal of Business Research, 68, 2634-2644.

Roy, S. K., Balaji, M. S., Soutar, G., Lassar, W. M. \& Roy, R. (2018a). "Customer engagement behavior in individualistic and collectivistic markets". Journal of Business Research, 86, 281-290.

Roy, S. K., Shekhar, V., Lassar, W. M. \& Chen, T. (2018b). "Customer engagement behaviors: The role of service convenience, fairness and quality". Journal of Retailing and Consumer Services, 44, 293-304.

Sekaran, U. \& Bougie, R. (2013). Research methods for business: A skill-building approach, Chichester; Hoboken, N.J, Wiley.

Simon, F. \& Tossan, V. (2018). "Does brand-consumer social sharing matter? A relational framework of customer engagement to brand-hosted social media". Journal of Business Research, 85, 175-184.

Thakur, R. (2016). "Understanding customer engagement and loyalty: A case of mobile devices for shopping". Journal of Retailing and Consumer Services, 32, 151-163. 
Thakur, R. (2018). "Customer engagement and online reviews". Journal of Retailing and Consumer Services, 41, 48-59.

Vera, J. \& Trujillo, A. (2013). "Service quality dimensions and superior customer perceived value in retail banks: An empirical study on mexican consumers". Journal of Retailing and Consumer Services, 20, 579-586.

Verhagen, T., Swen, E., Feldberg, F. \& Merikivi, J. (2015). "Benefitting from virtual customer environments: An empirical study of customer engagement". Computers in Human Behavior, 48, 340-357.

Verleye, K., Gemmel, P. \& Rangarajan, D. (2013). "Managing engagement behaviors in a network of customers and stakeholders: Evidence from the nursing home sector". Journal of Service Research, 17, 68-84.

Wardi, Y., Abror, A. \& Trinanda, O. (2018a). "Halal tourism: Antecedent of tourist's satisfaction and word of mouth (wom)". Asia Pacific Journal of Tourism Research, 23, 463-472.

Wardi, Y., Susanto, P., Abror, A. \& Abdullah, N. L. (2018b). "Impact of entrepreneurial proclivity on firm performance: The role of market and technology turbulence ". Pertanika J Soc. Sci. \& Hum, 26, 241-250.

Wong, C. Y., Boon-itt, S. \& Wong, C. W. Y. (2011). "The contingency effects of environmental uncertainty on the relationship between supply chain integration and operational performance". Journal of Operations Management, 29, 604-615.

Yao, T., Qiu, Q. \& Wei, Y. (2019). "Retaining hotel employees as internal customers: Effect of organizational commitment on attitudinal and behavioral loyalty of employees". International Journal of Hospitality Management, 76, 1-8.

Zamani-Farahani, H. \& Musa, G. (2012). "The relationship between islamic religiosity and residents' perceptions of socio-cultural impacts of tourism in iran: Case studies of sare'in and masooleh". Tourism Management, 33, 802-814. 
Table 1 Construct Reliability and Validity

\begin{tabular}{|c|c|c|c|c|c|c|c|}
\hline Constructs & Items & Mean & $\begin{array}{l}\text { Std. } \\
\text { Dev }\end{array}$ & Loading & $\alpha$ & CR & AVE \\
\hline \multirow[t]{10}{*}{ Service Quality } & & & & & 0.88 & 0.90 & 0.51 \\
\hline & Employees of this bank instill confidence in customers & 4.27 & 0.62 & 0.64 & & & \\
\hline & Employees of this bank are understanding of customers & 4.06 & 0.70 & 0.64 & & & \\
\hline & Employees of this bank serve customers in good manner & 4.38 & 0.59 & 0.60 & & & \\
\hline & $\begin{array}{l}\text { There is a warm relationship between employees of this } \\
\text { bank and customers }\end{array}$ & 4.00 & 0.78 & 0.71 & & & \\
\hline & $\begin{array}{l}\text { This bank does not make its customers stand in a queue } \\
\text { for a long time }\end{array}$ & 3.83 & 0.88 & 0.62 & & & \\
\hline & $\begin{array}{l}\text { Employees of this bank enact transactions on a timely } \\
\text { manner }\end{array}$ & 4.11 & 0.64 & 0.67 & & & \\
\hline & Employees of this bank always help customers & 3.80 & 0.80 & 0.65 & & & \\
\hline & $\begin{array}{l}\text { Employees of this bank provide individualized attention } \\
\text { to customers }\end{array}$ & 4.01 & 0.70 & 0.66 & & & \\
\hline & $\begin{array}{l}\text { Employees of this bank are willing to solve customer } \\
\text { problems }\end{array}$ & 4.19 & 0.68 & 0.64 & & & \\
\hline \multirow[t]{4}{*}{ Religiosity } & & & & & 0.80 & 0.82 & 0.61 \\
\hline & The Dua'aa (supplication) supports me. & 4.98 & 0.15 & 0.94 & & & \\
\hline & $\begin{array}{l}\text { The Prophet Muhammad (peace-be-upon-him) is the role } \\
\text { model for me. }\end{array}$ & 4.96 & 0.19 & 0.72 & & & \\
\hline & I believe that Allah (God) helps me. & 4.98 & 0.15 & 0.66 & & & \\
\hline \multirow[t]{3}{*}{ Satisfaction } & & & & & 0.87 & 0.89 & 0.81 \\
\hline & I am satisfied with the overall services of this bank & 4.26 & 0.60 & 0.89 & & & \\
\hline & The services of this bank meet my expectation & 4.15 & 0.70 & 0.91 & & & \\
\hline \multirow{4}{*}{$\begin{array}{l}\text { Customer } \\
\text { engagement }\end{array}$} & & & & & 0.82 & 0.85 & 0.65 \\
\hline & I intend to stay on as a customer of this bank & 4.20 & 0.76 & 0.79 & & & \\
\hline & I want to help other customers with their questions. & 4.00 & 0.74 & 0.82 & & & \\
\hline & I want to help the bank to improve its service. & 3.98 & 0.79 & 0.81 & & & \\
\hline \multirow{5}{*}{$\begin{array}{l}\text { Customer } \\
\text { Loyalty }\end{array}$} & & & & & 0.78 & 0.75 & 0.50 \\
\hline & I will increase the amount of my saving & 3.99 & 0.75 & 0.71 & & & \\
\hline & $\begin{array}{l}\text { I will use this Islamic bank in spite of the competitors' } \\
\text { deals. }\end{array}$ & 4.41 & 0.73 & 0.61 & & & \\
\hline & $\begin{array}{l}\text { I would prefer to use additional products and services in } \\
\text { this bank }\end{array}$ & 3.88 & 0.82 & 0.65 & & & \\
\hline & I will recommend this bank to others. & 4.18 & 0.78 & 0.76 & & & \\
\hline
\end{tabular}


Table 2 Discriminant Validity

\begin{tabular}{llllll}
\hline VARIABLE & 1 & 2 & 3 & 4 & 5 \\
\hline LOYALTY & .71 & & & & \\
SATISFACTION & $.47^{* * *}$ & .90 & & & \\
SERVQUAL & $.31^{* * *}$ & $.54^{* * *}$ & .71 & & \\
RELIGIOSITY & $.13^{* * *}$. & .10 & .05 & .78 & \\
CUSTOMER ENGAGEMENT & $.54^{* * *}$ & $.45^{* * *}$ & $.44^{* * *}$ & .06 & .81 \\
\hline
\end{tabular}

Note: Diagonal is the square root of AVE; $* * * \mathrm{p}$ value $<0.01 ; * * \mathrm{p}$ value $<0.05$

Table 3 Hypothesis Testing

\begin{tabular}{|c|c|c|c|c|}
\hline Hypothesis & Coefficient & SE & P Value & $\begin{array}{l}\text { Hypothesis } \\
\text { Verdict }\end{array}$ \\
\hline Servqual - Satisfaction & .608 & .052 & $0.000 * * *$ & Supported \\
\hline Servqual x Religosty-Satisfaction & -.134 & .115 & $0.006 * * *$ & Supported \\
\hline Servqual-Customer Engagement & .278 & .057 & $0.000 * * *$ & Supported \\
\hline Servqual-Loyalty & -.047 & .055 & $0.378^{\text {ns }}$ & Not Supported \\
\hline Satisfaction-Customer Engagement & .297 & .057 & $0.000 * * *$ & Supported \\
\hline Satisfaction-Loyalty & .307 & .056 & $0.000 * * *$ & Supported \\
\hline Customer Engagement-Loyalty & .427 & .051 & $0.000 * * *$ & Supported \\
\hline
\end{tabular}

$* * * \mathrm{p}$ value $<0.01 ; * * \mathrm{p}$ value $<0.05 ; \mathrm{ns}=$ Not Significant

Table 4 Moderated Mediation Model

\begin{tabular}{lll}
\hline \multicolumn{1}{c}{ Variable } & \multicolumn{1}{c}{ Model 1 } & \multicolumn{1}{c}{ Model 2 } \\
\hline Intercept & -.031 & -.014 \\
Service Quality & $.539^{* * *}$ & $.608^{* * *}$ \\
Religiosity & $.074^{\text {ns }}$ & $.048^{\text {ns }}$ \\
Interaction & & \\
Religiosity x Service Quality & & $-.134^{* *}$ \\
$\mathrm{R}^{2}$ & .300 & .312 \\
$\mathrm{R}^{2}$ Change & .012 & $.014^{* *}$ \\
F test & $71.042^{* * *}$ & $50.115^{* * *}$ \\
$* * *$ p value $<0.01 ; * *$ palue $<0.05 ; \mathrm{ns}=$ Not Significant &
\end{tabular}

$* * *$ p value $<0.01 ; * * \mathrm{p}$ value $<0.05 ; \mathrm{ns}=$ Not Significant 
Figure 1 Measurement Model

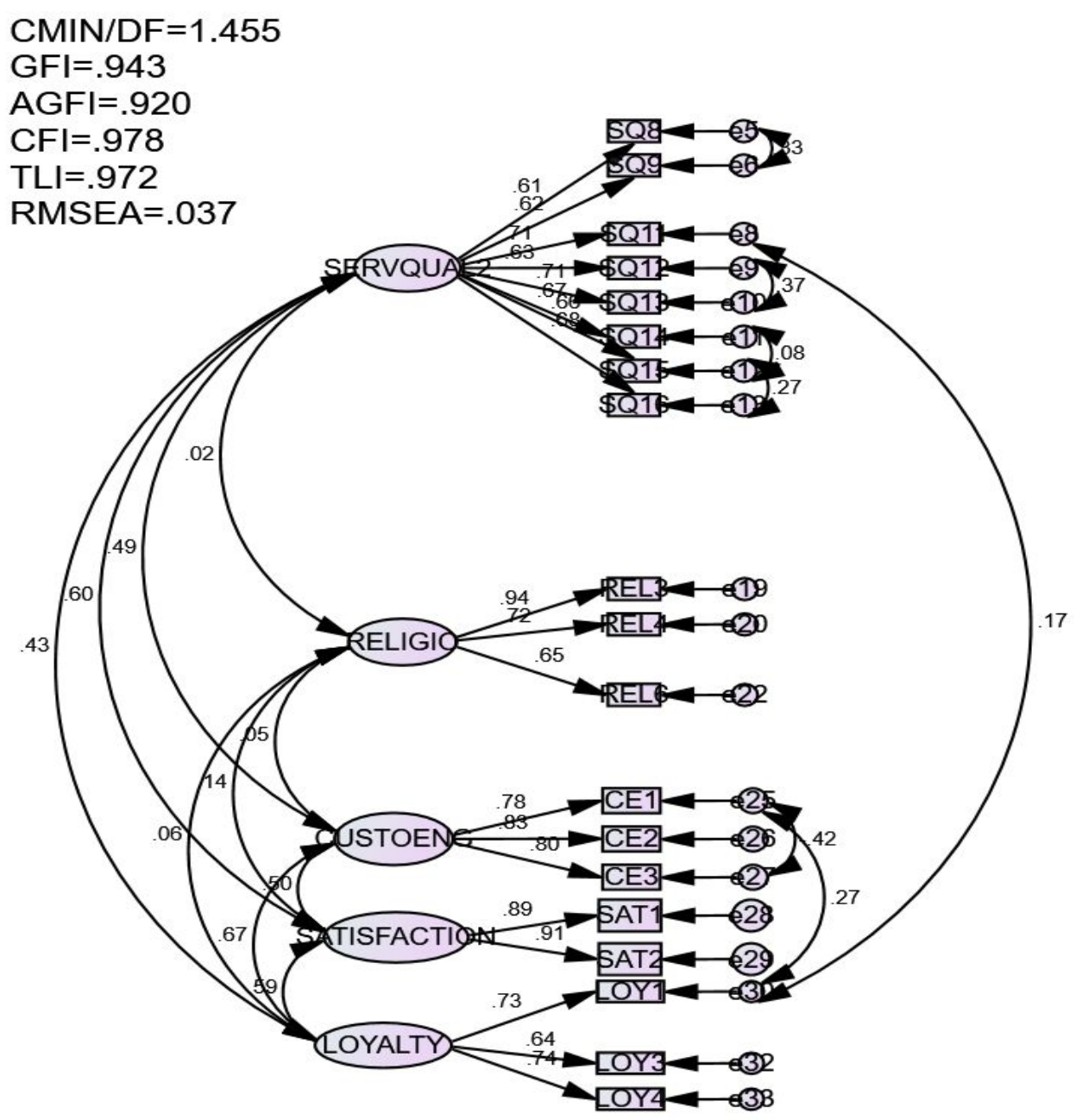


Figure 2 Research Model

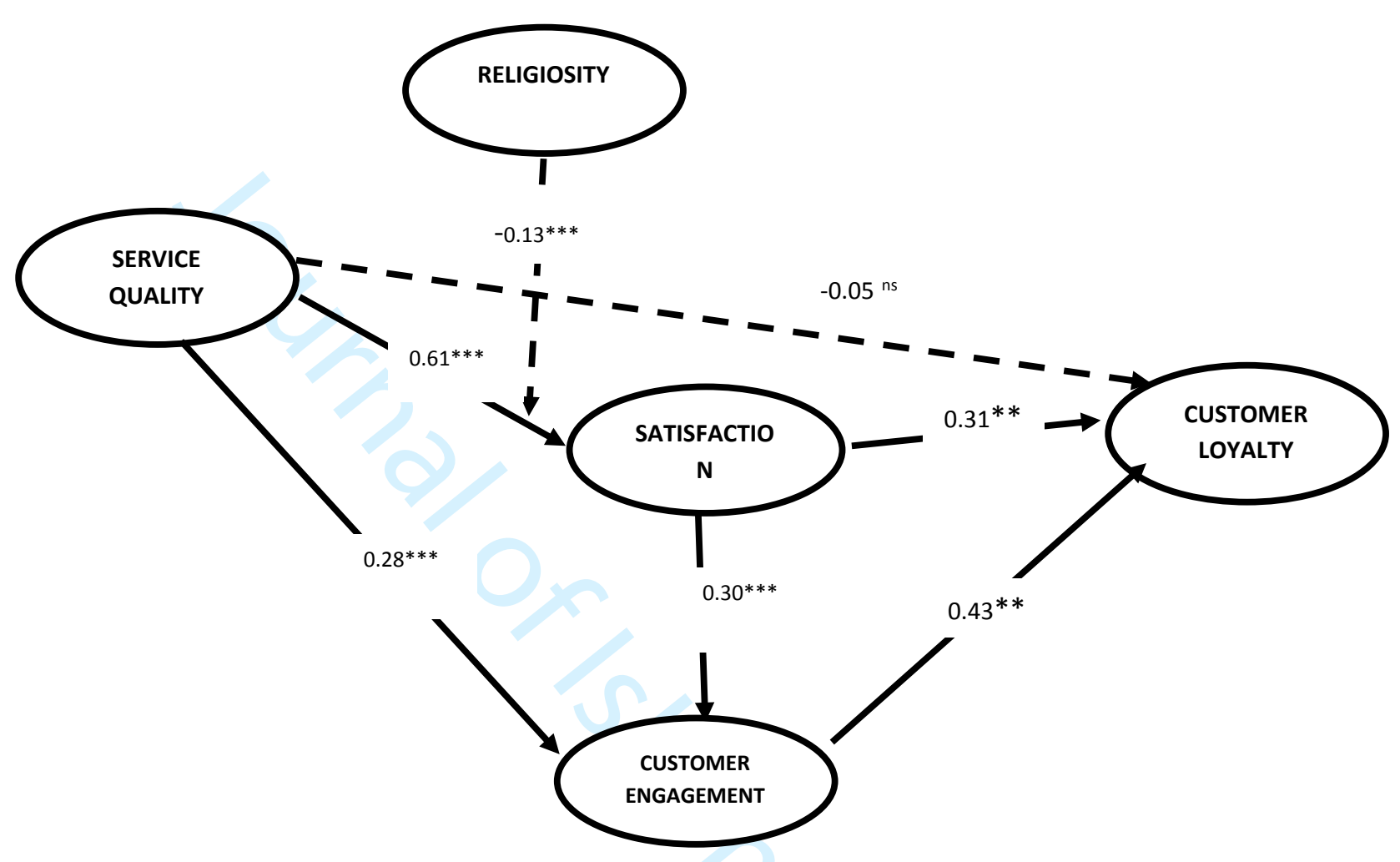


Figure 2: Interaction Effect

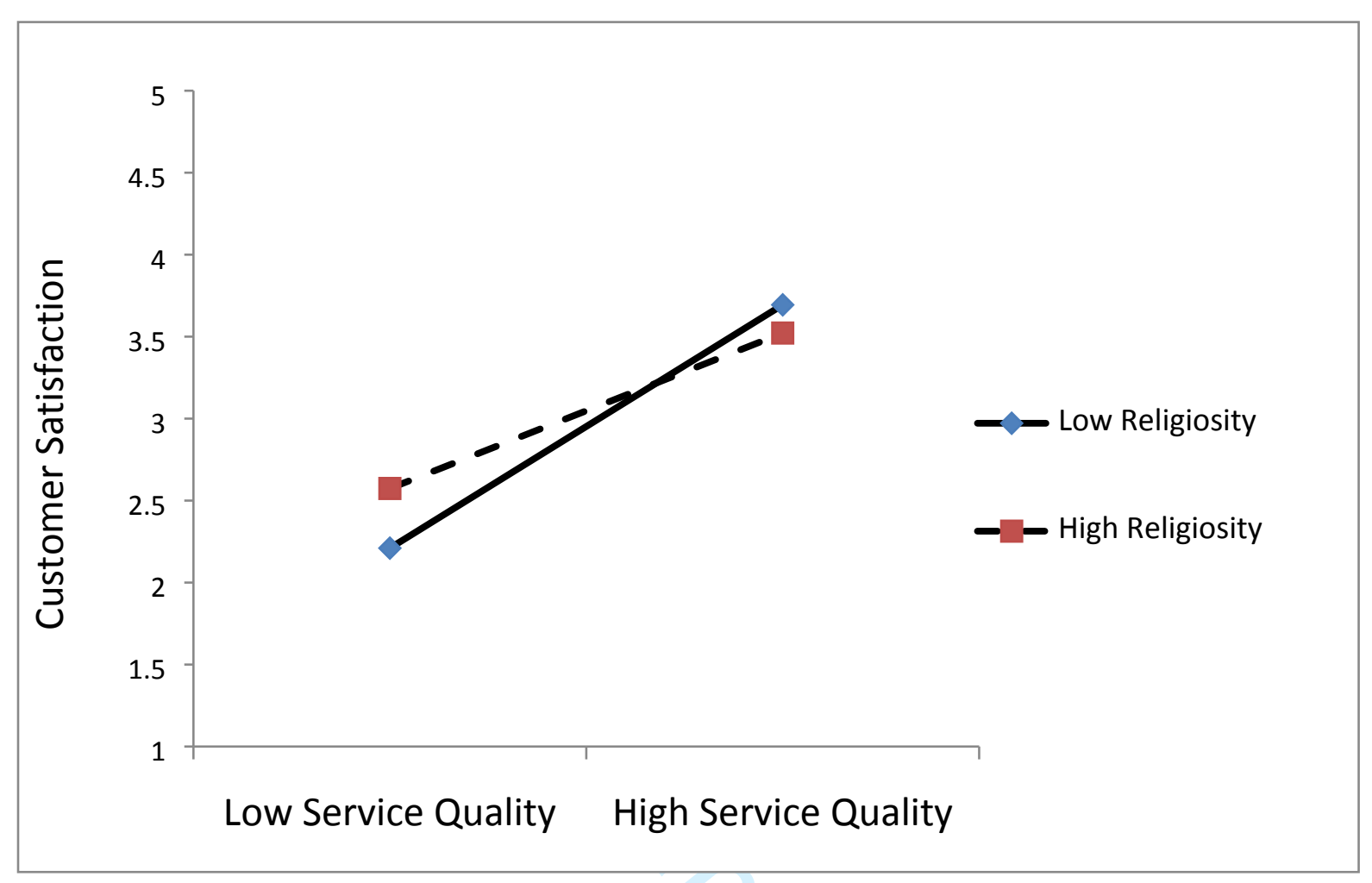

